\title{
Relativity Method on Online Advertisement
}

\author{
Gede Putra Yasa \\ STIKOM Bali, Denpasar, Indonesia \\ Email: gedeputrayasa@gmail.com
}

\begin{abstract}
As world development increases, current market developments have led to strategies that must be implemented by companies in offering and marketing their products. Online advertising is one effective method of promoting products within a company. Rolling over time consumers increasingly select all the desired products with the information available. Therefore, every company must be smart in choosing the right way to choose the company's products.

Keywords---advertisement, company, development, online, product.
\end{abstract}

\section{Introduction}

As it develops technology, communication is no longer a thing difficult to do. Communication is the transmission of a message from a sender to a receiver via a medium of transmission (Schiffman \& Kanuk 2000), which means communication is transmission of a message from the sender to the recipient through the transmission medium (Sangadji \& Sopiah, 2013). One form of communication between seller with buyer is advertisement. Through advertising the seller delivers the message aims to introduce its products sale, and invite consumers as message recipient to buy it. According to an article in mix magazine marketing communication in compiling effective communication program, the most important aspect is understanding the process of response from consumer. One of the problems of communicators marketing is determining responses from consumers, after determining responses from consumer marketing develop effective, ideal messages effective messages must attract attention (Rizki, 2015; Syakur \& Sukri, 2018), develops interest, arouses desire and move action. One form messages in communication are advertisements. Advertising is the most powerful tool to build awareness of a company, products, services, or ideas (Kotler \& Amstrong, 2010). Advertisement is one of the promotional tools used in marketing other than the salesperson, the public relations, sales discounts, and marketing directly. Advertising success and failure depends on how well the ad is capable communicate with information desires and the right attitude, at the right time, and at the right cost (Colley in Weilbacher, 2001).

In general, it can be said that to achieve success in achieving the target market of a company, a strategy that is right on target is needed. Therefore we need a marketer who is able to read the market situation and conditions appropriately (Chmielewski et al., 2018; Kaba, 2017). To reach the target in a marketing effort always requires tools in delivering information to consumers, one of which is by issuing advertisements about the products of a company that are attractive to consumers, which ultimately consumers will also be interested in using the products advertised. Submission of advertising will help in introducing products to consumers, advertising has an important role in plugging the brand of a product into the minds of consumers (Pratiwi et al., 2017).

The background above explains how important there is advertising in today's development. As well as advertising began to develop, from the form of speech into a form to television media that we can now see the products of each company vying to attract consumers. For this reason, I want to explore more about online advertising (Wang, 2011). 


\section{Discussion}

\section{Functions and Objectives Advertisement Online}

Function advertisement online initially, the function of advertising was only one way to strengthen the encouragement of consumers' needs and desires for a product to achieve satisfaction. But along with the times, advertising is the most important part of getting maximum profits. In addition to influencing consumers through material and visualization, advertising is also used to maintain consumers who have used the product to keep using it (Lu et al., 2010). Here are some functions of advertising in human life; Informing (providing information), providing knowledge to consumers so that they are aware of the company's products. Persuading, giving persuasions to the general public to try the products advertised by the company. Reminding (reminding), giving stimuli to the community to always remember the advertised product (Maimun \& Mandala, 2018; Pratiwi, 2016). Adding Value (providing added value), advertising must be able to provide value added products and influence consumer perceptions (positive). Assisting (assisting), one of the main functions of advertising is to assist or facilitate the efforts of other companies.

Purpose advertisement online, basically, the ultimate goal of advertising, whether done by personal or corporate, is to stimulate sales. There are several examples of advertising goals, namely:

1. Awaken the communicant and provide information about a product (can be goods, services, ideas, etc.).

2. Attempting to create a sense of liking to the communicant for the advertised product by providing preferences.

3. Convincing the connection of the truth of the product so that they are the company to own or use the product.

4. From the consumer's point of view, consumers become aware of information about the product, both price, specifications, functions, etc.

Method advertisement online. There are several methods that can be done to implement online advertising, namely:

1. Banner

On a webpage, the display of graphic ads is connected to the advertiser's webpage

2. Keyword Banner

Banner advertisements that appear when a predetermined word is questioned from a search engine

3. Random Banner

Ad banners that appear randomly, not as a result of user actions

4. Swapping Banner

An agreement / agreement between two companies for each display of another banner ad on its website

5. Banner Exchanges

A market where companies can trade or exchange banner ad placements on their respective websites

6. Pop-up Ad

An advertisement that appears in a separate window before, after, or while surfing the internet or when reading e-mail

7. Pop-under Ad

An ad that appears below the browser window that is used, so that when the user closes the active window the ad is still on the screen

8. E-Mail Advertising

An advertisement in e-mail

9. Newspaper-Like and Classified Ads

Classified Ads are a very common form of advertising in newspapers, online and other magazines that can be sold or shared free of charge.

Types advertisement online. The types of online advertising that are scattered in the internet network are currently very diverse. The variety of types of online advertising certainly has the character and advantages of each. The types of online advertising on the internet are:

1. Direct Advertising

Where advertisers and media owners deal directly and sign contracts to display advertisements or other promotional initiatives. 
Pros: The speed of the promotion process because many companies use this form of advertising as a means to eliminate the need to sell products through third parties.

Weaknesses: Lack of breadth of marketing because there is no third party that helps marketing. Requires a lot of time in meetings between advertisers and media owners.

\section{Self-service Advertising}

A new advertising approach where advertising material, ad placement, display and text is done by advertisers themselves through a process method that is carried out by themselves online.

Example: Blogads and Google AdWords.

Strengths: Advertisers can explain products through owned blogs, accompanied by images of products or services being promoted.

The disadvantages: Can not determine or predict the market, because it is done independently by the company in a blog and so on.

\section{Ad Networks}

An advertising network that connects and mediates between advertisers and website owners. Ad networks like this usually target campaigns that do not have a specific target audience, but aim for as many people as possible to see advertisements as little as possible. Examples: Value Click Media and Tribal Fusion.

4. Pros: The cost of advertising is quite cheap, not too expensive.

The drawback: The number of prospective customers is not too much if the ads posted on the web are not too many visited by internet users.

Online advertising, internet marketing (internet marketing), too referred to as marketing-I, web-marketing, online marketing or e-marketing, or e-commerce is the marketing of products or services via the internet. Internet marketing also refers on media placement along with various stages from the cycle of customer engagement through search engine marketing (Hermawan, 2012). According to Monle \& Johnson (2011) have various media online advertising, namely:

1. Online social network online social network or media network social has been very popular in the community and companies looking for communication media with other people or consumers. Based on Forrester research, 75\% of users the internet participates in several types of media social growth percentage of consumer activity on the internet is at social network or blog. Next network social which is widely used for move by consumers:

2. Facebook

Facebook is the biggest social media, with a total of more than $310,000,000$ users in the world. With the largest ad display source from all networks are social, with 14.7\%. 3. Twitter Mini blogs that allow individuals and company to send tweets, with maximum of 140 characters per message. Twitter can become an effective method for get consumers.

4. Websites

Website advertisements are more complex than types other than online advertising. Individuals must choose the snediri to visit the web they want, so it's a probability attention to who chooses to visiting the web is 1.00 .

5. Internet and advertising (Monle \& Johnson, 2011) When October $27^{\text {th }} 1994$ where Hot Wired was launched through online media namely web, Hotwired develop advertising online since the start of cable television.

That matter make marketers try even more to make a web a tool their advertising beside magazines, television, and radio.

1. Contextual Advertising

Ads targeted at content. Ads are not displayed randomly, but have been chosen by the system automatically according to the content relevant to the ad. Examples: Google AdSense and Yahoo Publisher Network.

Strengths: Ad position is chosen by the right system according to the product being promoted, so it is likely to be seen by many internet users or prospective consumers.

Drawbacks: Ads targeted at content. Ads are not displayed randomly. Ad position is chosen by the system, so the consumer market cannot be determined by the advertiser.

2. In-Text Advertising

The in-text advertising system automatically connects certain words on the website with related ad content.

Example: Kontera and Vibrant in-Text Ad. 
Strengths: Can make it easier because it connects certain words in the website with advertising content that is related and makes it easier to find advertisements that are sought or desired.

Weaknesses: Many ads that appear that might just be less relevant to what is intended. Prospective customers cannot be predicted by advertisers.

3. Rep Ad Agencies

Advertising agencies that represent certain blogs and websites and mediate their sales for large campaigns carried out by big brands or large advertising agencies. Examples: Federated Media and Tribal Fusion.

Strengths: Make it easy to promote, and predictions first because the agency helps with marketing strategies through this form of advertising.

Disadvantages: The cost of spending advertising will be greater, because through several parties the provider of advertising space and intermediaries.

4. Social Advertising

Advertising for social media. Unlike traditional advertising, this ad format utilizes the dynamics of social influences such as the influence of peer groups, word of mouth, viral marketing and recommendations directly from friends to friends. Examples: VideoEgg and Meebo.

Strengths: Promotion through Social Advertising is used on social media that is widely used by internet users, making it easier for promotions and cheaper costs.

Weaknesses: Must have advertisements posted on other websites or blogs to facilitate the promotion process. Feedback provided takes a long time.

5. Video Advertising

Ad forms targeted at video content. Various formats are available, including dynamic ads that can appear before, after, or during the appearance of certain video content. Example: Voxant and AdSense for Video.

Strengths: A variety of formats are available, including dynamic advertisements that make it more attractive that can appear before, after, or during the display of certain video content.

Drawbacks: Users who see these ads do not have a good connection. Ads cannot be seen to the full. Users tend to ignore the contents of advertisements because they focus on the video content they are targeting.

6. RSS Advertising

This ad is displayed in the RSS Feed, which can be adjusted to the context of the RSS feed content or manually targeted at specific promotional needs. Examples: Pheedo and Feedvertising.

Strengths: Can adjust ad placement through classification of predetermined needs.

Weaknesses: Not visible to all users because they have been classified.

7. Sponsorship

Is a form of financial assistance or it can be in the form of a product or service instead of promoting a brand.

Online sponsorship is an alternative strategy that is widely used and is considered more effective than banner advertising online.

Strengths: More effective because it doesn't require promotion anymore, it can be in exchange for promotion. And more effectively used to sponsor events related to company products or services.

The disadvantage: Requires a large amount of money. There is no explanation about the product or service, because it usually only takes the form of a company logo.

\section{Conclusion}

Online advertising is a way to promote a product on the Internet using various features of the Internet. With the advent of the internet, the business world has become digital and people prefer to buy things online, which is easier and faster. Online advertising known as e-advertising provides a new dimension and appeal that is unique to the product, which is an added advantage. In conclusion, online advertising is the cheapest and effective success proves it's potential. 


\section{References}

Chmielewski, S., Samulowska, M., Lupa, M., Lee, D. J., \& Zagajewski, B. (2018). Citizen science and WebGIS for outdoor advertisement visual pollution assessment. Computers, Environment and Urban Systems, 67, 97-109.

Colley, L. (2005). Britons: forging the nation, 1707-1837. Yale University Press.

Hermawan, H. (2012). Biodegradable metals: from concept to applications. Springer Science \& Business Media.

Kaba, A. (2017). Online library job advertisement in United Arab Emirates: a content analysis of online sources. Library Management, 38(2/3), 131-141.

Kotler, P., \& Armstrong, G. (2010). Principles of marketing. Pearson education.

Lu, G., Chand, J., Call, B., Scott, A., \& Urrabazo, R. (2010). U.S. Patent No. 7,783,617. Washington, DC: U.S. Patent and Trademark Office.

Maimun, M., \& Mandala, H. (2018). Ideology in tempo magazine advertising: a critical discussion analysis. International research journal of management, IT and social sciences, 5(6), 40-51.

Monle, L., \& Johnson, C. (2011). Prinsip-prinsip Pokok Periklanan Dalam Perspektif Global. Edisi pertama, Penerbit Kencana Prenada Media Grup Jakarta.

Pratiwi, D. P. E. (2016). Register analysis of indonesian advertisements. International journal of linguistics, literature and culture, 2(2), 27-37.

Pratiwi, D. P. E., Ayomi, P. N., \& Candra, K. D. P. (2017). Representation of Bali in tourism advertisement videos. International journal of linguistics, literature and culture, 3(5), 14-25.

Rizki, A. M. (2015). Advertising as a marketing communication. International research journal of management, IT and social sciences, 2(5), 23-25.

Sangadji, E. M. Sopiah. 2013. Perilaku konsumen.

Syakur, A. A., \& Sukri, M. (2018). Text of cigarette advertisement: A semiology study of Roland Barthes. International journal of linguistics, literature and culture, 4(3), 72-79.

Wang, T. (2011). Sensitivity analysis for newsvendor model with general advertisement-sensitive demand. Procedia Engineering, 15, 1209-1213.

Weilbacher, W. M. (2001). Point of view: Does advertising cause a 'hierarchy of effects'?. Journal of Advertising Research, 41(6), 19-26. 